\title{
EFFECTIVENESS OF THE IMPLEMENTATION OF MEANINGFUL INSTRUCTIONAL DESIGN LEARNING MODEL IN IMPROVING INTEREST AND STUDENT LEARNING OUTCOMES OF PHYSICS IN CLASS X SENIOR HIGH SCHOOL
}

\author{
Sulistia Budi* \\ Senior High School (SMA) 1 Pekanbaru \\ e-mail: sulistiabudi8@gmail.com
}

\begin{abstract}
The purpose of this action research is to increase the interest and learning outcomes of physics students with the implemention of the Meaningful Instructional Design Model (MID). The influence of internal factors experienced by students in learning physics include difficulties in understanding the material and solving the questions correctly, so that students' learning interest is low. Meaningful Instructionnal Design Model includes a learning model that prioritizes learning meaningfulness, which should be able to increase students' interest and learning outcomes. This research is a classroom action research conducted in two cycles. The subjects of this study were students of class XI MIPA4, SMA Negeri 1 Pekanbaru. The research instrument used observation sheets for interest and test sheets for physics learning outcomes in fluid material. Data is analyzed descriptively in percentage representation. The results of the research obtained the interest of students in physics learning, experiencing an increase from cycle I to cycle II. The same thing for learning outcomes of physics students also increased from cycle I to cycle II, with the average results obtained very good category. Thus the implementation of the Meaningful Instructionnal Design (MID) model is effective in increasing interest and learning outcomes of students of class XI MIPA4 SMA Negeri 1 Pekanbaru, in learning fluid material.
\end{abstract}

Keywords: Physics learning outcomes, meaningful instruction design, interest in learning, fluids.

\section{EFEKTIVITAS PENERAPAN MODEL PEMBELAJARAN MEANINGFUL INSTRUCTIONAL DESIGN DALAM MENINGKATKAN MINAT DAN HASIL BELAJAR FISIKA SISWA KELAS X SMA}

\author{
Sulistia Budi \\ SMA 1 Pekanbaru \\ e-mail: sulistiabudi8@gmail.com
}

\begin{abstract}
Abstrak
Tujuan penelitian tindakan ini untuk meningkatkan minat dan hasil belajar fisika peserta didik dengan penerapan model Meaningful Instructionnal Design. Pengaruh dari faktor internal yang dialami peserta didik dalam belajar fisika antara lain kesulitan dalam memahami materi dan pemecahan soal-soal dengan benar, sehingga minat belajar peserta didik rendah. Model Meaningful Instructionnal Design termasuk model pembelajaran yang mengutamakan kebermaknaan belajar, yang seharusnya dapat meningkatkan minat serta hasil belajar peserta didik. Penelitian ini merupakan penelitian tindakan kelas yang dilakukan dalam dua siklus. Subyek penelitian yaitu peserta didik kelas XI MIPA, SMA Negeri 1 Pekanbaru. Instrumen penelitian menggunakan lembar observasi untuk minat belajar dan lembar tes untuk hasil belajar fisika pada

${ }^{*)}$ Komunikasi Penulis
\end{abstract}


materi fluida. Data dianalisis secara deskriptip dalam representasi persentase. Hasil penelitian diperoleh minat belajar peserta didik terhadap pembelajaran fisika, mengalami peningkatan dari siklus I ke siklus II. Hal yang sama untuk hasil belajar fisika peserta didik juga meningkat dari siklus I ke Siklus II, dengan hasil rata-rata diperoleh katagori sangat baik. Dengan demikian penerapan model Meaningful Instructionnal Design (MID) efektif dalam meningkatkan minat dan hasil belajar peserta didik kelas XI MIPA 4 SMA Negeri I Pekanbaru, dalam mempelajari materi fluida.

Kata Kunci: hasil belajar fisika, meaningful instructionnal design, minat belajar, fluida.

\section{Pendahuluan}

Masalah rendahnya hasil belajar fisika pada peserta didik tidak dapat diselesaikan tanpa mengerti dahulu apa sebab hasil belajar tersebut tidak maksimal. Drost (2002) mengemukakan bahwa materi kurikulum terutama untuk mata pelajaran dasar di seluruh dunia pada dasarnya sama, yang berbeda adalah metode atau cara guru mengajarkannya didepan kelas. Cara guru mengajar didepan kelas itu justru lebih menentukan kualitas pendidikan. Tujuan penting dari pembelajaran adalah mengembangkan kemampuan mental yang memungkinkan seseorang dapat belajar (Degeng, 2001). Jadi belajar itu sendiri yang menjadi tujuan pembelajaran. Keaktifan peserta didik menjadi unsur yang sangat penting dalam menentukan kesuksesan belajar. Belajar samgat ditentukan adanya karsa individu dari peserta didik.

Pemahaman peserta didik terhadap suatu materi pun sangat kurang, terbukti pada saat guru memberikan tugas, peserta didik tidak segera mengerjakan melainkan sibuk saling bertanya kepada teman dan teman yang ditanya pun kadang memiliki kompetensi yang kurang dalam memberikan jawaban, tidak jarang peserta didik mengeluh tentang sulitnya mencari jawaban dari tugas tersebut. Untuk mengatasi rendahnya minat dan hasil belajar fisika di kelas XI $\mathrm{MIPA}_{4}$, maka salah satu alternative yang dilakukan guru adalah menerapkan model pembelajaran MID (Meaningful Instructionnal Design). Model ini merupakan pembelajaran yang mengutamakan kebermaknaan belajar dan efektifivitas dengan cara membuat kerangka kerja-aktivitas secara konseptual kognitif-konstruktivis.

Pembelajaran lebih ditekankan pada kontek dan pemahamam individu yang lebih bermakna (meaningful). Penyelesaian masalah menggunakan berbagai sumber daya infor- masi, misalnya media cetak, media audio, media audio visual, multimedia, internet, dan teknologi terpadu. Hal ini berbeda dengan pengembangan pembelajaran yang berpijak pada teori behavioristik, pengembangan pembelajaran diarahkan pada penyelesaian tugas atau penguasaan pengetahuan secara sistematik. Metode pembelajaran meaningful learning merupakan strategi dasar dari pembelajaran konstruktivistik. Ausubel memberikan penjelasan terkait istilah meaningful learning bahwa manusia ingin mengetahui keadaan sekelilingnya, apakah lingkungan sosial, lingkungan alam bahkan lingkungan spiritual. Untuk menjawab itu semua pertama manusia harus menggunakan panca indra. Ketika manusia mengamati peristiwa sosial dengan panca indra, bagaimana ia bisa memastikan bahwa apa yang diterima adalah sama seperti peristiwa yang sebenarnya (Shoimin, 2014).

Menurut Ausubel dan Novak (dalam Dahar, 2011) menyatakan bahwa terdapat tiga kebaikan belajar bermakna yaitu:

1. Informasi yang dipelajari secara bermakna lebih lama diingat.

2. Informasi baru yang telah dikaitkan dengan konsep-konsep relevan sebelumnya dapat meningkatkan konsep yang telah dikuasai sebelumnya sehingga memudahkan proses belajar mengajar berikutnya untuk memberi pelajaran yang mirip.

3. Informasi yang pernah dilupakan setelah pernah dikuasai sebelumnya, meninggalkan bekas sehingga memudahkan proses belajar mengajar untuk materi pelajaran yang mirip walaupun telah lupa.

Ciri model pembelajaran Meaningful Instructional Design yaitu: a) Menggunakan pengalaman dan pengetahuan awal peserta didik, menerima informasi, memproses dan menyimpan informasi untuk dipanggil kembali (retrieval) bila mana diperlukan, b) Mem- 
pertimbangkan materi, minat, dan perkembangan kognitif peserta didik.

Selanjutnya proses berisi penentuan status awal dari pemahaman peserta didik, perumusan tujuan pembelajaran dan merancang "perlakuan" berbasis media untuk membantu terjadinya transisi. Idealnya, proses ini berdasarkan pada informasi dan teori belajar yang sudah teruji secara pedagogis dan dapat terjadi hanya pada peserta didik, dipandu oleh guru atau dalam latar berbasis komunitas. Model Meaningful Instructional Design adalah pembelajaran yang mengutamakan kebermaknaan belajar dan efektivitas dengan cara membuat kerangka kerja aktivitas secara konseptual kognitif-konstruktif.

Menurut Ahmad Shabri (2005) mengatakan hasil belajar yang dicapai peserta didik dipengaruhi oleh dua faktor utama yaitu faktor dari lingkungan dan faktor yang datang dari diri peserta didik. Djamarah (2002) memberikan indikator minat belajar yaitu rasa suka/senang, pernyataan lebih menyukai, adanya rasa ketertarikan, adanya kesadaran untuk belajar tanpa disuruh, berpartisipasi dalam aktivitas belajar, dan memberikan perhatian. Menurut Slameto (2010) beberapa indikator minat belajar yaitu: perasaan senang, ketertarikan, penerimaan, dan keterlibatan peserta didik. Dari beberapa definisi yang dikemukakan mengenai indikator. Untuk mengetahui tingkat minat peserta didik dalam kajian ini menggunakan aspek menurut. Apabila keempat aspek ini terpenuhi dengan baik berarti minatnya tinggi terhadap apa yang dipelajari (Slameto, 2010).

Selanjutnya minat belajar dapat berpengaruh terhadap hasil belajar peserta didik terhadap suatu pembelajaran. Menurut Purwanto (2011) bahwa hasil belajar adalah perubahan perilaku peserta didik akibat belajar. Perubahan perilaku disebabkan karena dia mencapai penguasaan atas sejumlah bahan yang diberikan dalam proses belajar mengajar.

Salah satu hasil dari penelitian yang berkaitan dengan model pembelajaran MID telah diketahuin yaitu dari penelitian yang telah dilakukan oleh Sritresna (2015). Penelitian yang dilakukan berfokus pada pengaruh model pembelajaran kooperatif tipe Meaningful Instructional Design (MID) terhadap peningkatan kemampuan koneksi matematik yaitu terkait pemahaman konsep matematika peserta didik. Berdasarkan hasil analisisnya, menunjukkan bahwa peningkatan kemampuan koneksi matematik peserta didik di kelas eksperimen berada pada level tinggi, sedangkan di kelas konvensional berada pada level sedang, sehingga dapat diperoleh bahwa peningkatan kemampuan koneksi matematika peserta didik yang mendapat model pembelajaran Cooperatif tipe MID lebih baik daripada peserta didik yang mendapatkan pembelajaran konvensional.

Berdasarkan uraian tersebut, maka tujuan dari penelitian ini adalah untuk meningkatkan minat belajar dan hasil belajar peserta didik melalui penerapan model pembelajaran Meaningful Instructional Design (MID) pada kelas XI MIPA $_{4}$ SMAN 1 Pekanbaru.

\section{Bahan dan Metode}

Metode yang digunakan dalam penelitian ini adalah penelitian tindakan kelas (Classroom Action Research). Penelitian ini dilaksanakan di SMAN 1 Pekanbaru yang berlokasi di jalan Sutan Syarif Qasim Kota Pekanbaru. Penelitian dilaksanakan pada bulan Agustus-September 2018. Subjek penelitian adalah peserta didik kelas XI MIPA SMAN $_{4}$ Pekanbaru yang berjumlah 35 orang, yang terdiri dari 15 peserta didik perempuan dan 20 orang peserta didik laki-laki.

Penelitian tindakan kelas ini terdiri dari dua siklus, dimana masing-masing siklus terdiri dari dua kali pertemuan. Materi pokok pada siklus I adalah tentang fluida statik (fluida tidak mengalir) sedangkan materi pokok pada siklus II adalah fluida dinamik (bergerak). Prosedur pelaksanaan meliputi empat komponen kegiatan yaitu: perencanaan (planning), tindakan (acting), pengamatan (observing), dan refleksi (reflecting) (Suharsimi Arikunto, 2006). Tahap yang dilakukan antara lain melaksanakan tindakan sesuai skenario dan RPP yang telah dirancang. Langkah-langkah pembelajaran sesuai dengan langkah-langkah pembelajaran model pembelajaran Meaningful Instructionnal Design.

Data diperoleh melalui observasi dan tes hasil belajar. Observasi adalah kegiatan pengamatan untuk mengetahui seberapa jauh efek tindakan telah mencapai sasaran yang dilakukan selama proses pembelajaran berlangsung. Sedangkan tes hasil belajar diguna- 
kan untuk mengukur atau mengevaluasi hasil belajar peserta didik yang dilaksanakan setelah tindakan setiap siklus.

Data tentang minat belajar peserta didik, diamati setiap pertemuan menggunakan skala likert yaitu 1 jika satu aspek yang muncul, 2 jika muncul 2 aspek, 3 jika muncul tiga aspek, dan 4 jika ke 4 aspek muncul sebagaimana dijelaskan pada bagian pendahuluan. Untuk memudahkan pengamatan, maka pengkaji dibantu dua orang guru sebagai obsever. Hasil pengamatan minat setiap siklus di analisis dengan mengkonversi dalam bentuk persentase (\%) yang memenuhi persamaan (1) dan kategorinya ditentukan menurut Tabel 1 . Hasil belajar dianalisis dari hasil tes essay bejumlah lima soal dimana setiap soal mempunyai nilai maksimal 20 dengan nilai akhir memenuhi persamaan (1) dengan kategori sesuai Tabel 1.

$$
p=\frac{f}{N} \times 100 \%
$$

dimana $\mathrm{p}$ adalah persentase minat atau hasil belajar, $f$ adalah frekuensi atau jumlah jawaban yang benar, $\mathrm{N}$ adalah jumlah skor maksimal yang diperoleh.

Tabel 1. Persentase minat dan hasil belajar

\begin{tabular}{ccl}
\hline No. & $\begin{array}{c}\text { Interval Penilaian } \\
(\mathbf{\%})\end{array}$ & \multicolumn{1}{c}{ Kategori } \\
\hline 1 & $81-100$ & Sangat baik \\
2 & $61-80$ & Baik \\
3 & $41-60$ & Cukup \\
4 & $21-40$ & Kurang \\
5 & $0-20$ & Tidak baik \\
\hline
\end{tabular}

Sumber: adaptasi dari (Riduwan, 2009).

Teknik analisa data dilakukan dengan cara analisis deskriftif terhadap minat dan hasil belajar. Minat dikatakan tinggi apabila memenuhi kategori baik atau sangat baik dan dikatakan rendah jika memenuhi kategori cukup, kurang atau tidak baik. Selanjutnya hasil belajar ditentukan tingkatnya berdasarkan kategori Tabel 1. Peningkatan dikatakan tinggi jika memenuhi KKM mata pelajaran fisika yaitu $\geq 75$ dengan kategori baik atau sangat baik.

\section{Hasil dan Pembahasan}

Berdasarkan hasil pengamatan yang dilakukan, secara keseluruhan peserta didik merasa senang dengan pembelajaran menggunakan model Meaningful Instructional Design. Peserta didik juga terlibat aktif dalam kegiatan-kegiatan pembelajaran secara langsung. Dengan seksama peserta didik mengamati praktek secara langsung tentang tekanan yang terjadi pada air, tekanan hidrostatis, hukum pascal, dan hukum arcimedes.

\section{Pelaksanaan tindakan siklus I}

Melalui tahap perencanaan guru menyiapkan hal-hal yang diperlukan dan dilakukan dalam penelitian diantaranya yaitu: 1) Menyusun rencana pelaksanaan, 2) Menyiapkan media pembelajaran, 3) Menyusun pedoman observasi, dan 4) Menyusun alat evaluasi peserta didik. Pada tahap tindakan yang dilakukan antara lain melaksanakan tindakan sesuai skenario dan RPP yang telah dirancang. Materi pembelajaran pada siklus I adalah tentang fluida diam. Langkah-langkah pembelajaran sesuai dengan langkah-langkah model pembelajaran MID (Meaningful Instructionnal Design).

Hal yang dilakukan pada tahap observasi yaitu melihat minat belajar peserta didik menggunakan lembar ceklis untuk mengamati minat belajar peserta didik. Aspek yang diamati adalah: 1) perasaan senang, 2) keterlibatan peserta didik, 3) ketertarikan, dan 4) perhatian peserta didik. Pengamatan dibantu oleh dua orang guru (Observer).

Tahap refleksi dilakukan pada akhir siklus untuk menentukan langkah-langkah berikutnya. Pada akhir siklus dilakukan evaluasi terhadap hasil belajar peserta didik, evaluasi ini bertujuan untuk mengetahui seberapa besar tingkat keberhasilan tindakan yang dilakukan.

Berdasarkan hasil pengamatan yang dilakukan, secara keseluruhan peserta didik merasa senang dengan pembelajaran dengan menggunakan metode ini. Peserta didik juga terlibat dalam kegiatan-kegiatan pembelajaran secara langsung. Dengan seksama peserta didik mengamati praktek secara langsung tentang tekanan yang terjadi pada air, tekanan hidrostatis, hukum pascal, dan hukum arcimedes. 


\section{Pelaksanaan tindakan siklus II}

Melalui tahap perencanaan dilakukan pada siklus II adalah sama dengan siklus I, pada tahap ini guru membuat rencana perbaikan tindakan berdasarkan hasil refleksi siklus sebelumnya. Siklus II merupakan penyempurnaan tindakan. Hal-hal yang menjadi kelemahan pada siklus I disempurnakan pada siklus ini. Media yang digunakan pada siklus II, disesuaikan dengan materi fluida bergerak. Pada tahap ini guru memberikan penguatan dengan cara menyatukan konsep yang sudah dibuat oleh peserta didik pada suatu kesimpulan yang logis. Pada saat pembetian latihan soal, guru memberikan soal yang berbeda kepada seluruh kelompok, dengan harapan seluruh peserta didik dapat terlibat dalam mengerjakan latihan soal-soal dengan kapasitas yang sama. Pada tahap observasi dilakukan oleh guru untuk melihat minat belajar peserta didik. Alat yang digunakan untuk observasi adalah lembar cek lis.

Selanjutnya tahap refleksi dilakukan pada akhir siklus dan dilakukan evaluasi terhadap minat belajar peserta didik. Secara klasikal kegiatan pembelajaran dengan penerapan model pembelajaran MID dapat meningkatkan minat belajar peserta didik terhadap pembelajaran fisika. Pada saat pembelajaran guru mengkaitkan pertanyaan pada materi pembelajaran yang sedang dipelajari oleh peserta didik melalui diskusi kelompok, Kegiatan tersebut dilakukan oleh guru dengan membagi peserta didik pada suatu kelompok dengan menjawab pertanyaan baru melalui pengamatan, pengetahuan, dan pengalaman peserta didik tersebut.

\section{Minat Belajar Peserta Didik}

Hasil pengamatan terhadap minat belajar peserta didik dilakukan dengan menggunakan lembar observasi yang dilakukan oleh bantuan guru lain pada saat pembelajaran berlangsung, pengamatan dilakukan secara individual sehingga guru dapat mengukur minat belajar peserta didik terhadap penerapan pembelajaran Meaningful Instructionnal Design ini. Peningkatan minat belajar peserta didik ditunjukkan dalam grafik Gambar 1.

Pada siklus I secara klasikal peserta didik yang memiliki minat belajar terhadap pembelajaran fisika berjumlah $77.1 \%$. Seluruh peserta didik terlihat senang pada saat pembelajaran, namun pada aspek keterlibatan peserta didik pada proses pembelajaran hanya berjumlah $54.3 \%$. Karena pada siklus I peserta didik yang pintar lebih mendominasi jalannya pembelajaran.

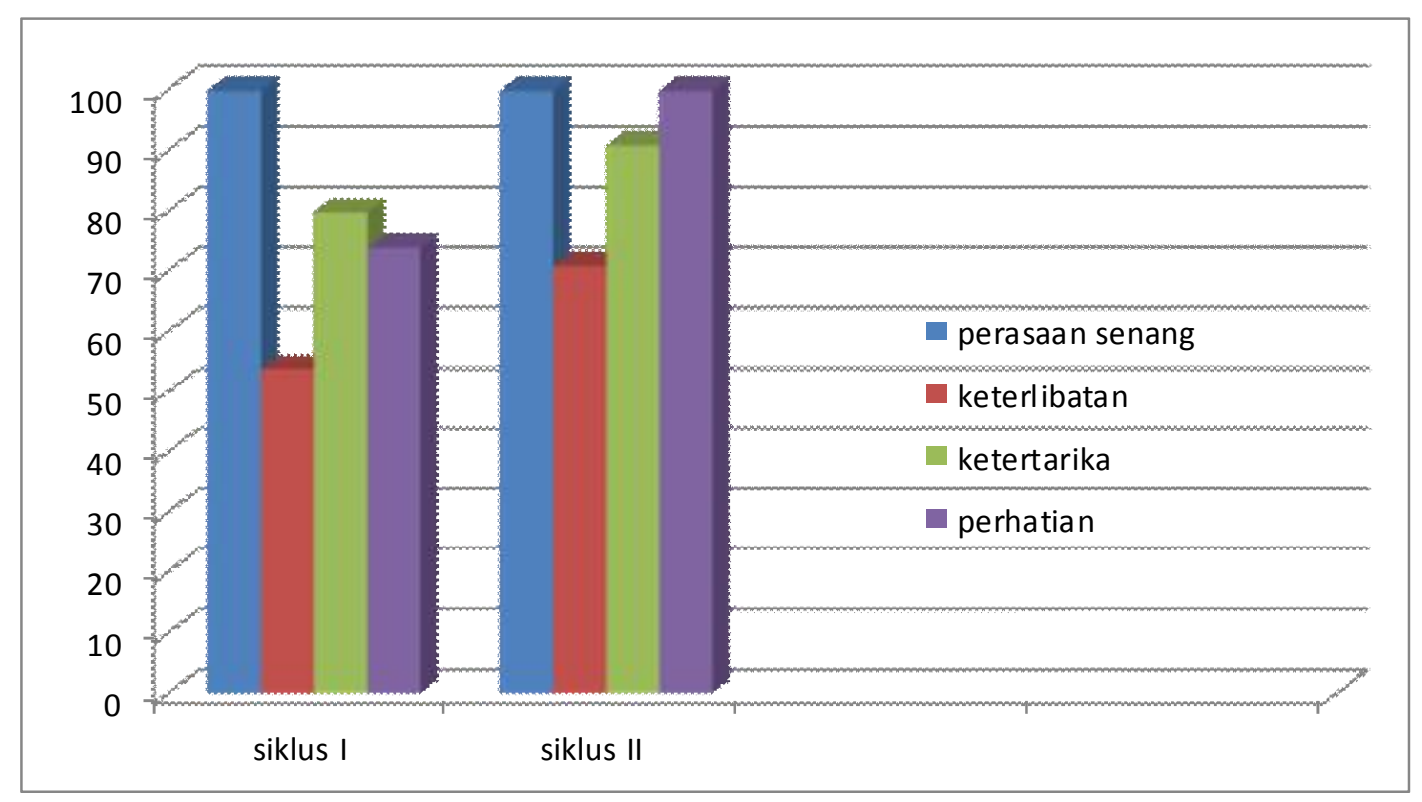

Gambar 1. Peningkatan Minat Belajar Peserta didik. 
Peserta didik yang terlihat tertarik dengan pembelajaran fisika berjumlah $80 \%$. Peserta didik yang terlihat mem-perhatikan penjelasan baik dari guru maupun dari teman lainya berjumlah $74.3 \%$. Indikator pencapaian yaitu $\geq 80 \%$ memiliki minat terhadap pembelajaran fisika belum tercapai pada siklus I.

Setelah dilakukan penyempurnaan dan perbaikan tindakan pada siklus II terjadi peningkatan minat belajar peserta didik. Pada siklus II secara klasikal peserta didik yang memiliki minat terhadap pembelajaran fisika berjumlah $90.75 \%$. Setiap indikator minat belajar mengalami peningkatan. Pada aspek perasaan senang dan perhatian memperoleh hasil yang maksimal, $100 \%$ peserta didik merasa senang dan tertarik dengan pembelajaran fisika meenggunakan penerapan model pembelajaran MID. Keterlibatan peserta didik dalam pembelajaran juga mengalami peningkatan menjadi $71.4 \%$, sedangkan aspek ketertarikan peserta didik meningkat menjadi $94.4 \%$.

Berdasarkan hasil analisis terhadap minat belajar, menunjukkan hasil yang positif dengan kategori sangat baik. Hal ini menunjuk kan minat belajar peserta didik tinggi setelah mengikuti pembelajaran siklus kedua. Dengan menggunakan model pembelajaran Meaningful Instructionnal Design, proses pembelajaran berpusat pada peserta didik, dimana mereka terlibat aktif dalam mengkonstruksi konsep yang dikaitkan pada kehidupan sehari-hari. Peserta didik dituntut untuk selalu aktif dalam proses pembelajaran dengan berusaha sendiri untuk mencari pengetahuan (Abdul Majid, 2014) pemecahan masalah serta pengetahuan yang menyertainya sehingga menghasilkan pengetahuan yang benar-benar bermakna. Sehingga proses pelaksanaan pembelajaran maupun tujuan yang dicapai terlaksana dengan baik.

Berdasarkan hasil penelitian dan pembahasan yang telah dikemukakan, maka dapat diketahui bahwa model pembelajaan Meaningful Instructionnal Design (MID) dapat meningkatkan minat belajar peserta didik dalam pembelajaran fisika pada materi fluida.

\section{Hasil Belajar}

Data hasil belajar peserta didik diperoleh memalui tes hasil belajar yang dilakukan pada akhir setiap siklus. Peningkatan hasil belajar peserta didik ditunjukkan pada grafik dalam Gambar 2.

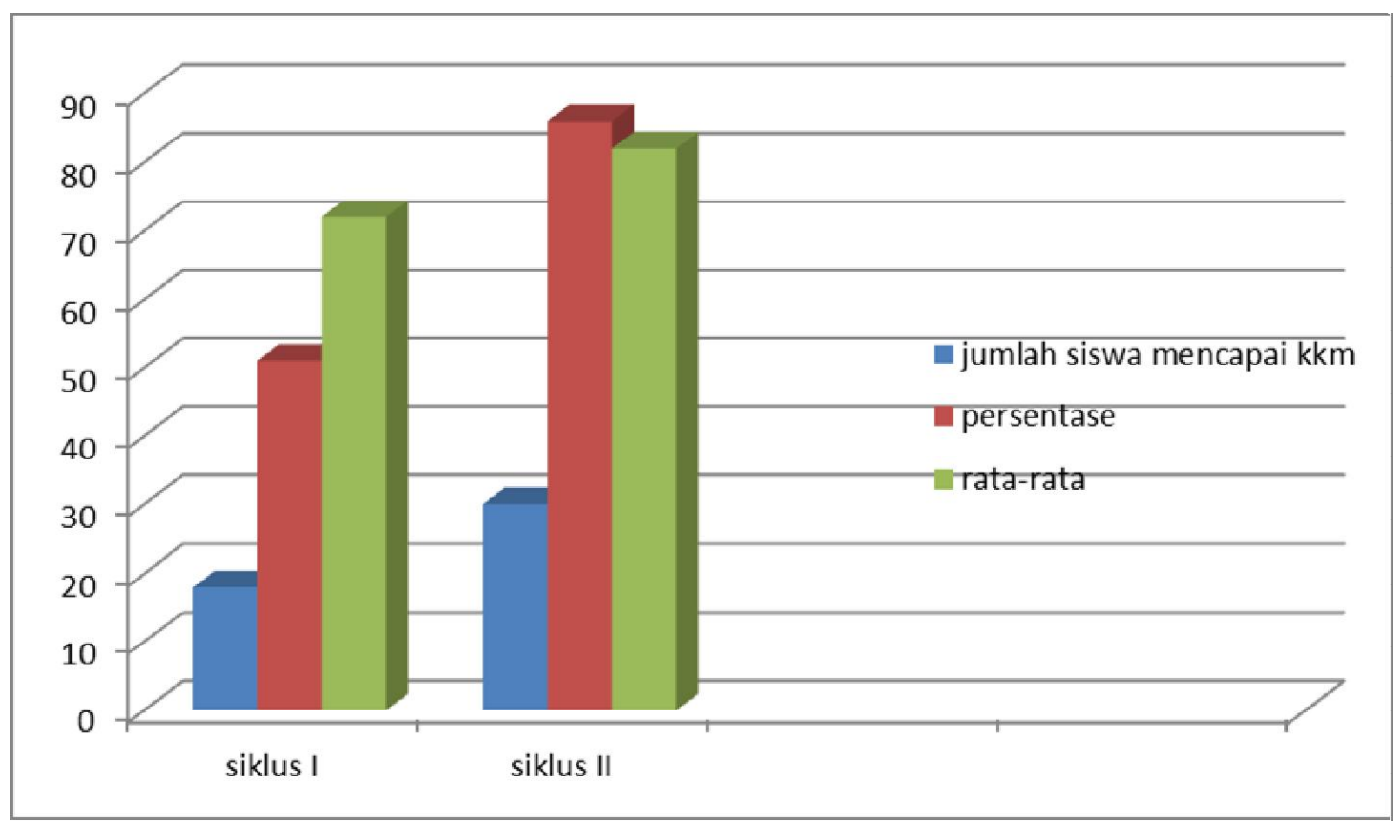

Gambar 2. Peningkatan hasil belajar peserta didik. 
Hasil belajar fisika pada siklus I dikategorikan masih rendah, karena hanya 18 orang atau $51.4 \%$ peserta didik yang mencapai KKM. Rata-rata kelas adalah 72 , dengan nilai tertinggi adalah 90 dan nilai terendah adalah 60. Indikator keberhasilan yaitu $\geq 75 \%$ peserta didik mencapai KKM belum tercapai pada siklus I. Pada siklus II terjadi peningkatan hasil belajar peserta didik, sehingga dikategorikan tinggi. Ketuntasan belajar pada siklus II adalah $85.7 \%$, rata-rata kelas adalah 81.9 .

Terjadinya peningkatan hasil belajar fisika dari siklus I ke Siklus II ini, menunjukan bahwa penerapan model pembelajaran MID dapat meingkatkan hasil belajar fisika. Melalui penerapan model pembelajaran MID dapat membantu peserta didik untuk mengembangkan pengertian dan pemahaman konsep secara lengkap. Peserta didik dapat mengkaitkan informasi yang dia dapat dengan pemahaman memereka sendiri dan merancang dengan detail apa yang dia dapatkan.

Peningkatan hasil belajar fisika ini menunjukkan bahwa dengan penerapan model pembelajaran MID dapat meingkatkan hasil belajar fisika. Hal ini senada dengan hasil kajuan dikemukakan oleh (Sritresna, 2015) bahwa perapan model pembelajaran MID mampu membantu peserta didik untuk memahami bahan belajar secara lebih mudah. Kelebihan model ini juga dapat membantu peserta didik menjawab persoalan yang dipelajari sesuai kemampuannya dan mudah diingat melalui mencari informasi-informasi baru. Melalui penerapan model pembelajaran MID dapat membantu peserta didik untuk mengembangkan pengertian dan pemahaman konsep secara lengkap.

\section{Kesimpulan dan Saran}

Penerapan model pembelajaran MID berhasil dalam meningkatkan minat belajar fisika peserta didik dari siklus I kategori cukup (rendah) ke siklus II dengan kategori sangat baik (tinggi). Penerapan model ini juga berhasil dalam meningkatkan hasil belajar peserta didik dari siklus I kategori cukup (rendah) ke siklus II dengan kategori sangat baik (tinggi). Penerapan model pembelajaran MID (Meaningful Instructionnal Design) efektif dalam meningkatkan minat dan hasil belajar fisika pada materi fluida bagi peserta didik kelas XI MIPA 4 SMAN 1 Pekanbaru.

Disarankan pada guru mata pelajaran fisika dapat menggunakan model pembelajaran MID sebagai salah satu alternatif pemilihan model pembelajaran. Diperlukan penataan yang lebih terstruktur dan sinkron antara model MID dengan materi yang diberikan dalam pembelajaran untuk mencapai hasil yang lebik maksimal.

\section{Daftar Pustaka}

Abdul Majid, 2014. Strategi Pembelajaran. Remaja Rosdakarya, Bandung.

Ahmad Shabri, 2005. Strategi Belajar Mengajar dan Micro Teaching. Quantum Teaching, Jakarta.

Degeng, I Nyoman S., 2001. Mencari Pendekatan Baru Pemecahan Masalah. Belajar. UNM, Malang.

Dahar, Ratna Willis, 2011. Teori Belajar dan Pembelajaran. Erlangga, Jakarta.

Djamarah, 2002. Rahasia Sukses Belajar. Rineka Cipta, Jakarta.

Drost, J,. 2003. Proses Pembelajaran Sebagai Proses Pendidikan. Jakarta.

Purwanto, 2011. Evaluasi Hasil Belajar. Pustaka Pelajar, Yogyakarta.

Riduwan, 2009. Belajar Mudah Penelitian untuk Guru, Karyawan dan Peneliti Pemula. Alfabeta, Bandung.

Slameto, 2003. Belajardan Faktor-faktor yang Mempengaruhinya. Rineka Cipta, Jakarta.

Shoimin, Aris, 2014. Model Pembelajaran Inovatif Dalam Kurikulum 2013. ArRuzz Media, Yogyakarta.

Sritresna, T., 2015. Meningkatkan Kemampuan Koneksi Matematis Siswa Melalui Model Pembelajaran CooperativeMeaningful Instructional Design $J$. Mtk. Vol 5 No. 1. April 01, 2015. http://jurnalmtk.stkip-garut.ac.id/data/ edisi5/vol1/teni.pdf.(02Februari2019).

Suharsimi Arikunto, 2006. Prosedur Penelitian Suatu Pendekatan Praktik. Rineka Cipta, Jakarta.

Susanto. Ahmad, 2014. Teori Belajar dan Pembelajaran di Sekolah Dasar. Kencana, Jakarta. 